\title{
Skin and mucosal manifestations of an AIDS-related systemic mycosis
}

\begin{tabular}{|c|c|}
\hline $\begin{array}{l}\text { Authors: } \\
\text { Michael T. Bos } \\
\text { Liam Robinsor } \\
\text { Nelesh Goven }\end{array}$ & $\begin{array}{l}\text { well } \\
\text { we } \\
\operatorname{ler}^{1,2} \text { (1) } \\
\operatorname{lic}^{4,5}\end{array}$ \\
\hline $\begin{array}{l}\text { Affiliations: } \\
\text { }{ }^{2} \text { Department } \\
\text { Medicine, Sch } \\
\text { Faculty of Hea } \\
\text { University of P } \\
\text { Pretoria, Soutl }\end{array}$ & $\begin{array}{l}\text { f Internal } \\
\text { ol of Medicine, } \\
\text { Ith Sciences, } \\
\text { retoria, } \\
\text { Africa }\end{array}$ \\
\hline $\begin{array}{l}{ }^{2} \text { Department } \\
\text { Medicine, Ste } \\
\text { Academic Hos } \\
\text { South Africa }\end{array}$ & $\begin{array}{l}\text { f Internal } \\
\text { ve Biko } \\
\text { pital, Pretoria, }\end{array}$ \\
\hline $\begin{array}{l}{ }^{3} \text { Department } \\
\text { Pathology and } \\
\text { School of Den } \\
\text { of Health Scie } \\
\text { of Pretoria, Pr } \\
\text { South Africa }\end{array}$ & $\begin{array}{l}\text { Oral } \\
\text { Oral Biology, } \\
\text { tistry, Faculty } \\
\text { nces, University } \\
\text { etoria, }\end{array}$ \\
\hline $\begin{array}{l}{ }^{4} \text { Centre for } \mathrm{H} A \\
\text { Mycoses, Nati } \\
\text { for Communic } \\
\text { Johannesburg }\end{array}$ & $\begin{array}{l}\text { Is, AMR and } \\
\text { onal Institute } \\
\text { able Diseases, } \\
\text { South Africa }\end{array}$ \\
\hline $\begin{array}{l}{ }^{5} \text { Faculty of } \mathrm{He} \\
\text { Sciences, Univ } \\
\text { Witwatersranc } \\
\text { South Africa }\end{array}$ & $\begin{array}{l}\text { alth } \\
\text { ersity of the } \\
\text {, Johannesburg, }\end{array}$ \\
\hline $\begin{array}{l}\text { Correspondin } \\
\text { Michael Bosw } \\
\text { boswell.micha }\end{array}$ & $\begin{array}{l}\text { s author: } \\
\text { ell, } \\
\text { elt@gmail.com }\end{array}$ \\
\hline $\begin{array}{l}\text { Dates: } \\
\text { Received: } 23 \text { I } \\
\text { Accepted: } 09 \\
\text { Published: } 28\end{array}$ & $\begin{array}{l}\text { lov. } 2020 \\
\text { Jec. } 2020 \\
\text { Jan. } 2021\end{array}$ \\
\hline $\begin{array}{l}\text { How to cite th } \\
\text { Boswell MT, R } \\
\text { Govender N. S } \\
\text { mucosal mani } \\
\text { of an AIDS-rel } \\
\text { systemic myco } \\
\text { Med. } 2021 ; 22 \\
\text { https://doi.org } \\
\text { sajhivmed.v22 }\end{array}$ & $\begin{array}{l}\text { is article: } \\
\text { binson L, } \\
\text { kin and } \\
\text { estations } \\
\text { ted } \\
\text { sis. S Afr J HIV } \\
1 \text { ), a1198. } \\
\text { /10.4102/ } \\
1.1198\end{array}$ \\
\hline Read online: & \\
\hline 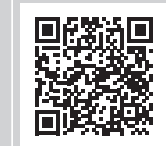 & $\begin{array}{l}\text { Scan this QR } \\
\text { code with your } \\
\text { smart phone or } \\
\text { mobile device } \\
\text { to read online. }\end{array}$ \\
\hline
\end{tabular}

\section{Authors:}

\section{Affiliations}

Medicine, School of Medicine, Faculty of Health Sciences,

University of Pretoria,

${ }^{2}$ Department of Internal Medicine, Steve Biko Academic Hospital, Pretoria,

${ }^{3}$ Department of Ora

Pathology and Oral Biology, of Pretoria, Pretoria

${ }^{4}$ Centre for HAls, AMR and for Communicable Diseases,

${ }^{5}$ Faculty of Health Sciences, University of the Witwatersrand, Johannesburg, Corresponding author: Michael Boswell,

Received: 23 Nov 2020 Accepted: 09 Dec. 2020

How to cite this article: Boswell MT, Robinson L, Govender N. Skin and of an AIDS-related systemic mycosis. S Afr J HIV 2021;22(1), a1198. https://doi.org/10.4102/
A human immunodeficiency virus (HIV)-positive male from Cameroon who had recently started antiretroviral therapy presented with a new rash, night sweats and loss of weight. On examination, erythematous to flesh-coloured papules were noted on the trunk (a). Intraoral examination revealed granular-appearing lesions of the hard and soft palate, with areas of pigmentation in keeping with HIV-associated mucosal hyperpigmentation (b). A full blood count showed a pancytopenia, with a moderate neutropenia. He had a severe lymphopenia, and his CD4+ T-cell count was 46 cells/microlitre $(\mu \mathrm{L})$. Serum (1-3)- $\beta$-d-glucan and ferritin levels were markedly elevated at $>500$ picograms per millilitre $(\mathrm{pg} / \mathrm{mL})$ and 5533 micrograms per litre $(\mu \mathrm{g} / \mathrm{L})$, respectively. Periodic Acid-Schiff with Diastase (PAS-D) and Grocott-Gomori histochemical stains of a skin punch biopsy showed numerous small, round intracytoplasmic organisms within histiocytes, consistent with histoplasmosis (c and d) (see Figure 1). A pan-fungal polymerase chain reaction (PCR) assay confirmed infection with either Histoplasma capsulatum or Emergomyces africanus. This PCR assay cross-reacts with Blastomyces species; however, the yeast phase of this pathogen has a different histological appearance.
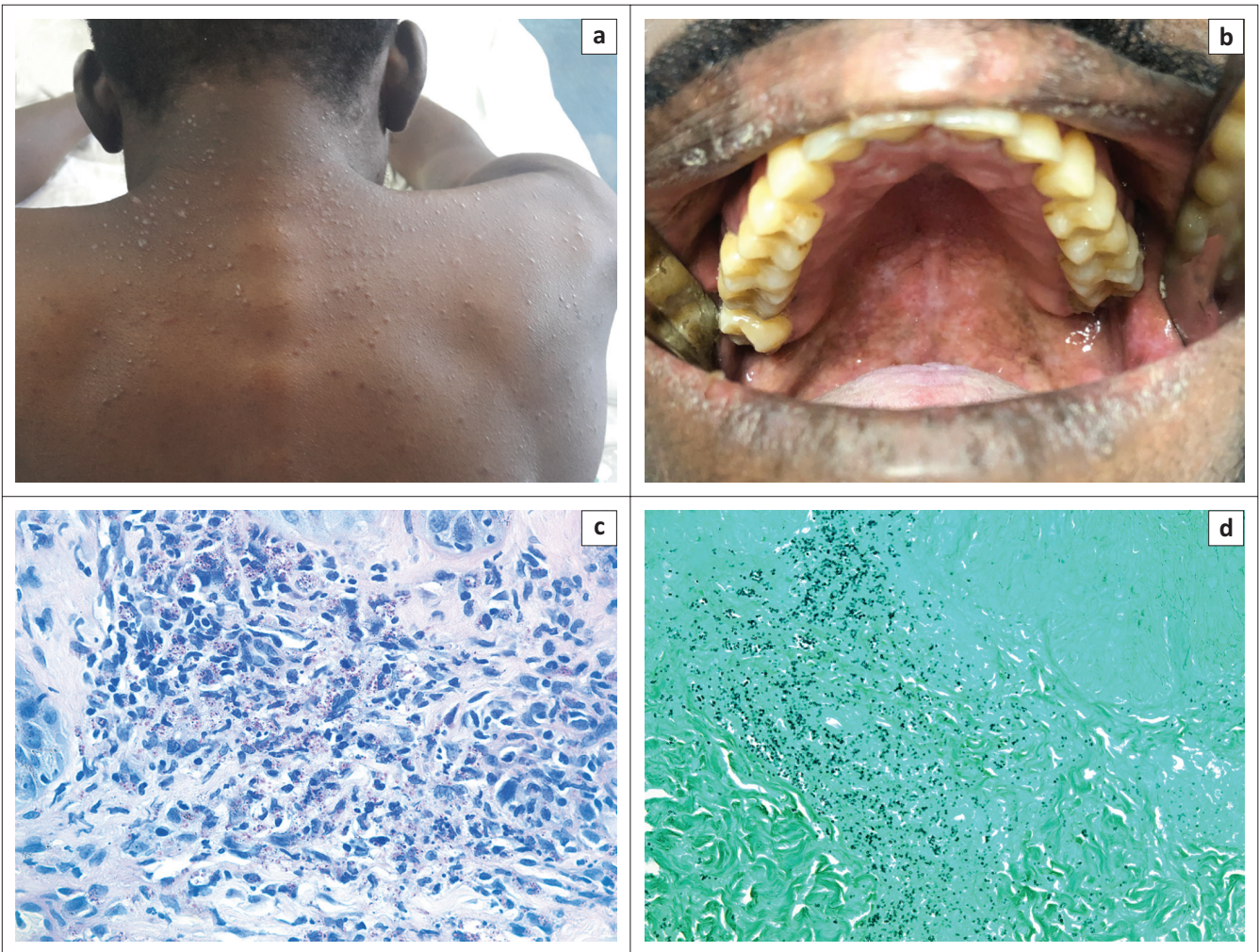

FIGURE 1: (a) Erythematous to flesh-coloured papules on the trunk; (b) Granular-appearing, pigmented lesions involving the hard and soft palate; (c) PAS-D and (d) Grocott-Gomori stained sections highlighting the intracytoplasmic organisms (original magnification $\times 200$ ).

\section{Acknowledgements}

The authors would like to thank Theresa Rossouw, Tarryn Jacobs and Glynn Dale Buchanan for their help on earlier versions of this manuscript and input on the management of this case.

\section{Competing interests}

The authors have declared that no competing interests exist.

Copyright: (C) 2021. The Authors. Licensee: AOSIS. This work is licensed under the Creative Commons Attribution License. 


\section{Authors' contributions}

All authors contributed to the case management and drafting of this manuscript.

\section{Funding information}

This research did not receive any specific grant from funding agencies in the public, commercial or not-for-profit sectors.

\section{Data availability statement}

Data sharing is not applicable to this article, as no new data were created or analysed in this study.

\section{Disclaimer}

The views and opinions expressed in this article are those of the authors and do not necessarily reflect the official policy or position of any affiliated agency of the authors. 